\title{
Javanese Women in Old Literature Text: Literature Ethnography Study
}

\author{
E Ismawati ${ }^{1}$, Warsito $^{2}$, KA Anindita ${ }^{3}$ \\ \{1 esti@unwidha.ac.id ${ }^{2}$ warsito.unwidha@gmail.com ${ }^{3}$ andyan.anindito@gmail.com\} \\ ${ }^{1,2}$ Universitas Widya Dharma, ${ }^{3}$ Universitas Negeri Surakarta
}

\begin{abstract}
The focus of this research is Javanese women in the old literary text, a literary ethnography study. The problems to be answered are how is the description of Javanese women in old Javanese literary texts? What is the role and their social economic status? The method used is ethnography, with the technique of note taking notes. The data sources of this study are: old Javanese literary text, informant, and document. The ethnographic method examines behaviour that takes place within specific social situations, including behaviour that is shaped and constrained by these situations, plus people's understanding and interpretation of their experiences. From the results of the analysis it can be concluded that Javanese women in the old literary text are in two positions, which are confined in the house because of the hegemony of the power of men in concubine, parameswari (first lady) and free positions in women traders and farmers. Women from the lower classes enjoy this confined condition. Javanese women of ordinary class have a strategic social and economic role, which are ready to be abandoned by men (divorced), but Javanese priyayi women (the king's wife and relatives in the palace) are precisely described otherwise, although they can also be proud of themselves because they become royal families. Their role is supported by the family they are from.
\end{abstract}

Keywords: status and role, Javanese women, old literary texts

\section{Introduction}

Javanese women are an interesting phenomenon. Their figure, activity, life, can be written ethnographically. Javanese women of the past were very familiar with terms, phrases, or idioms such as: not being allowed to go out, made into concubines, being appointed as parameswari (queen consort), and being restricted in their status and role as a friend in kitchen. That is a mirror of the lives of Javanese women of the past. Not being allowed to go out means being held at home. Concubines are often called garwa ampeyan, klangenan, meaning women who have been bound by family ties by a man, but do not have the status of wife in general terms. Their status is under the wife (ampeyan) and their job is to make men always happy (klangenan). A concubine is an illegitimate wife. Whereas, prameswari is the term for the king's wife or queen consort. The term parameswari has been known since the age of the kingdom in Indonesia [1]. Javanese women in literary texts are also very interesting 
to study because literature is a mirror of their society. There are many studies on Javanese women, but critical and solvable studies as in this article do not yet exist.

Status and role are two sides of a coin that are interrelated, a very important thing in the lives of Javanese women. Status is position, and role is expected behavior or normative behavior that is attached to that status. In social systems, individuals occupy a place (status), and act (role) in accordance with the norms made by the system [2]. The initial status of each normal individual is the status of a child in a kinship unit, related to gender. The sex itself for certain communities (for example Java, Islam) has determined the superiority of status with all its consequences. In the role structure, a normal man must have a 'job' that is fundamental for his status, because this 'job' will be the main source of income and class status of his wife and children [3]. However, in terms of a woman's role, the situation is different. Most women, if they are married and do not work or even if they work, they will not change their husband's status. This is in accordance with the Javanese proverb: suwarga nunut neraka katut (going to heaven or hell is because of their husbands, women are only complementary and not decisive). The most fundamental of the family status is the husband's status and father's job. The status from their position of their job achieved by the individuals determines family's status in the social structure. To a certain extent the humanistic aspect of women's roles is only partially institutionalized, so it is not surprising that the patterns often carry signs of tension and anxiety [4]. The title of this article has no pretension to favor Javanese women, because racial differences can be the root of social conflict when followed by racism, the belief of a group that assumes that their racial group is superior to other races. Racism is often used as a reason for a group to behave as the race with the most civilization as well as other races that are not civilized [5].

During the colonial period (Dutch and Japanese) Javanese women were treated badly (they became mistresses, lived without status), second-class citizens, and had little access to various needs such as education, government and community activities until of RA. Kartini, the initiator of women's struggle who inspired women. The women's struggle from time to time underwent changes, from fighting the colonials to fighting the issue of education and equal rights for women [6]. The culmination of the feeling of wanting to fight together was manifested in the First Women's Congress which was held in Yogyakarta on December 22-25, 1928, initiated by women's organizations, including Wanito Utomo, Women Taman Siswa, Aisyiah, Putri Indonesia, Wanita Katolik, Jong Java Bagian Gadis [7]. The role of women in the national movement was very prominent, even though at that time women did not have any status. Javanese women in literary texts are widely known from various backgrounds, ranging from low class to high class, ranging from ordinary women to noble women. They include Nyai Ontosoroh created by Pramudya Ananta Tour; Genduk Duku, Lusi Lindri, Rara Mendut, Larasati, Rosi Padmakristi created by YB Mangunwijaya; Bu Bei Tuginem created by Arswendo AW; Ngaisah (Nyonya Sastrodarsono), Sri Sumarah, Bawuk created by Umar Kayam. Srintil created by Ahmad Tohari. Sri, Kedasih created by Nh. Dini. All of them were Javanese women in fiction. Nobody has discussed Javanese women in poetry or geguritan.

A lot of research on Javanese women in new literary texts, as seen in the paragraph above, but there is no research on Javanese women in old literary texts, especially the status and role of Javanese women in old Javanese poetry texts or geguritan. This research to try to fill the void by using purposive sampling, which is a selected old literary works. The problems that will be answered in this research are how is the description of Javanese women in old Javanese literary texts (geguritan)? What is their status and socioeconomic role of Javanese women? How do literary writers put their status and role of Javanese women society in their work? 
Tirto Suwondo [8] grouped old Javanese literature based on its contents into 6 groups, namely Piwulang containing moral teachings, Suluk containing teachings of perfection namely the advice about sangkan paraning dumadi dan manunggaling kawula langusti, Jangka, containing prophecy, Babad containing stories related to history, Roman containing romantic life stories, and Pewayangan containing puppet stories. Examples of Piwulang texts are such as Wedhatama, Wulang Reh, Panitisastra, Asthabrata, Tambangprana, Sewaka, Sana Sunu, Candra Rini, Wulang Estri, Tripama, Wedharaga, Nitisruti Lugu, Dumbasawala, Wirawiyata, and many more. Examples of Suluk texts are such as Suluk Seh Ngabdul Salam, Suluk Seh Siti Jenar, Suluk Seh Amongraga. Examples of the Jangka texts include Jaka Lodang, Kalatidha, Sabda Tama, Sabda Jati. Example of Babad texts is Babad Joko Tingkir. Example of Javanese Romance is Cemporet. Example of Pewayangan texts is Serat Kandhaning Ringgit Purwa.

In Old Javanese literature which is generally in the form of 'kakawin' and New Javanese literature which is generally in the form of 'babad', the term 'parameswari' (queen consort) has been found [1]. Kakawin is a literary work in the form of poetry or song originated from the period before 1500 . Babad is a literary work in the form of song originated from the period after 1500 (the era of the development of Islamic kingdoms on the island of Java. The difference is Kakawin praises the ruling king, Babad praises the ruling dynasty. Kakawin does not connect the king who rules with the previous one, babad always connects. Examples of Kakawin are such as Kakawin Arjunawiwaha, Kakawin Kresnajaya, Kakawin Sumanasantaka.

What is told in kakawin Sumanasantaka text is the birth of King Dasarata in Ayodya. Bagawan Trenawindu was imprisoned, the gods feared that later he would attack and conquer the Indera kingdom. The angel named Harini was ordered by Bathara Indera to be seductive. The Harini was condemned by the Trenawindu to go down to earth, became a human, then transformed into a daughter in the land of Widarba, named Dewi Indumati the son of king Karthakesika [9]. Here women were given the task to tempt, to thwart a person who was meditating.

Ismawati, [10] in her study entitled "Karakter Perempuan Jawa dalam Novel Indonesia Berwarna Lokal Jawa: Kajian Perspektif Gender dan Transformasi Budaya" concludes that Javanese women in Indonesian novels about Javanese culture have played active roles in their lives. They are no longer konco wingking, who do not contribute something but also work in the public and domestic sectors. They contribute to the family's income, even as the breadwinners. This discription is contained in the literary ethnography by YB Mangunwijaya Burung-Burung Manyar, Canting by Arswendo Atmowiloto, Pada Sebuah Kapal by Nh. Dini, Para Priyayi by Umar Kayam, Ronggeng Dukuh Paruk by Ahmad Tohari, Sri Sumarah and Bawuk by Umar Kayam, and Tirai Menurun by Nh. Dini.

In Code of the Street, 1999, Anderson conducted ethnographic research to examine the social order of a community in inner city Philadelphia. He argues that activity and behavior in the neighborhood are characterized by one of two 'codes.' The 'code of the street' is one that places highest value on interpersonal respect and makes regular use of the threat of physical violence to assert one's self. While outsiders commonly stereotype all inner-city residents as acting in accordance with this code, many residents in fact follow the 'decent' code, which reflects middle-class values, personal responsibility, and participation in the mainstream economy instead of illegitimate activities. In the context of these conflicting codes, community residents develop the ability to regularly switch between codes to adapt to different situations [11]. 


\section{Research Method}

The object of this research is Javanese women in old literature text. The data sources of this study are: first, old Javanese literature texts in the form of poetry or geguritan; second, informant; and third, documents (from observations). Ethnography is a study of society and human culture that is prepared according to the views and experiences of researchers living in the community with a holistic analysis [12][13]. Ethnography is the most appropriate way to describe the reality of the people studied. Ethnography becomes a bridge between theoretical thinking and the reality of everyday life caught by anthropologists [14]. Literary ethnography arose from writers who acted as ethnographers, such as Umar Kayam in the novel Para Priyayi, Ahmad Tohari in Ronggeng Dukuh Paruk, Linus Suryadi AG in Pengakuan Pariyem, Nh. Dini in Pada Sebuah Kapal. These are some examples from Javanese ethnography which can be used as a study of ethnographic literature, also in the old literature as done in this study. The data analysis technique of this research uses hermeneutic analysis and descriptive analysis.

The ethnographic perspective was conceived by Creswell [15]. The steps taken by literary ethnographers are to describe the attitudes of ethnic cultural behavior, by describing the ups and downs of ethnic members and aesthetically describing the community life in terms of culture, to describe events, unique cases in an ethnic group that deserve to be a way of life, to describe certain ethnic views on life that can be emulated and to present the unique character of an ethnic group that includes ethics and manners. This research focuses on Javanese culture. The techniques used are 1) taking some literary texts as material for its descriptive analysis, 2) open ended interview with literary writers, 3) direct observation by living in a Javanese community in a rural area for life, in this case in the village of Tegalrejo, Bayat Subdistrict, Klaten Regency, Central Java Province, Indonesia, 4) giving the meaning/interpretation of texts, 5) triangulation of the results of the interpretation of texts with Javanese cultural experts. Literary texts analyzed include both old literary texts originating from the court poets and writers outside the palace. The discussion of the old literary text was carried out in the library of Mangkunegaran Surakarta with triangulation of meaning by Javanese cultural experts from the Surakarta palace KRT Darajadi Gondodiprojo and Dra. Darweni, MHum.

\section{Results And Discussion}

Many Javanese teachings relate to the role of Javanese women, which, if examined only show that women are weak, women must be willing to live a polygamous marriage life, at home, and great in pleasing their husbands. Some of the books that contain the teachings are Wulang Estri by Paku Buwana X and Candra Rini by Raden Ngabehi Ranggawarsita [16]. The book of "Wulang Estri by Paku Buwana X contains the teachings of domestic life, which focuses on the role of the wife, which is always loyal and obedient to the husband, as symbolized by the five fingers: jempol, tuduh, panunggul, driji manis, jenthik (thumb, index finger, middle finger, ring finger, pinkie finger). Jempol means that a wife must sincerely "satisfy" her husband. Panunggul means superior. The meaning is that the husband must always be favored, valued, respected. Tuduh, pituduh means clue. The wife must always follow the instructions of the husband. Driji manis means that the wife must always be sweet in front of her husband. Jenthik, uthik means the wife must be skilled and creative. In addition 
to these five things, women must be happy to live a polygamous marriage life, even finding girls for husbands. If she does not want her husband to have another wife, she will be divorced because she is a woman who is not commendable. This clearly does not give a place for the role of intelligent Javanese women, thinkers and policy makers, who have been dominated by men.

The book of Candra Rini by Raden Ngabehi Ranggawarsita contains household teachings intended for women. The concept stated in Candra Rini is a description of the nature, character, and behavior of Arjuna's wife in wayang, Subadra or Sembadra. The traits are loyalty to the husband, willingness to live a polygamous marriage life, loving others, being skilled, having great sense of fashion, taking care of themselves well, being responsive, being interesting, being simple, satisfying husbands well, and fond of reading books. A princess must also hold fast to the three traits: bekti, nastiti, wedi (devoted, meticulous, fearful), fear of making mistakes.

The obedience of Javanese women to their husbands is found in Serat Nitipraja [17], as described in the following lyrics:

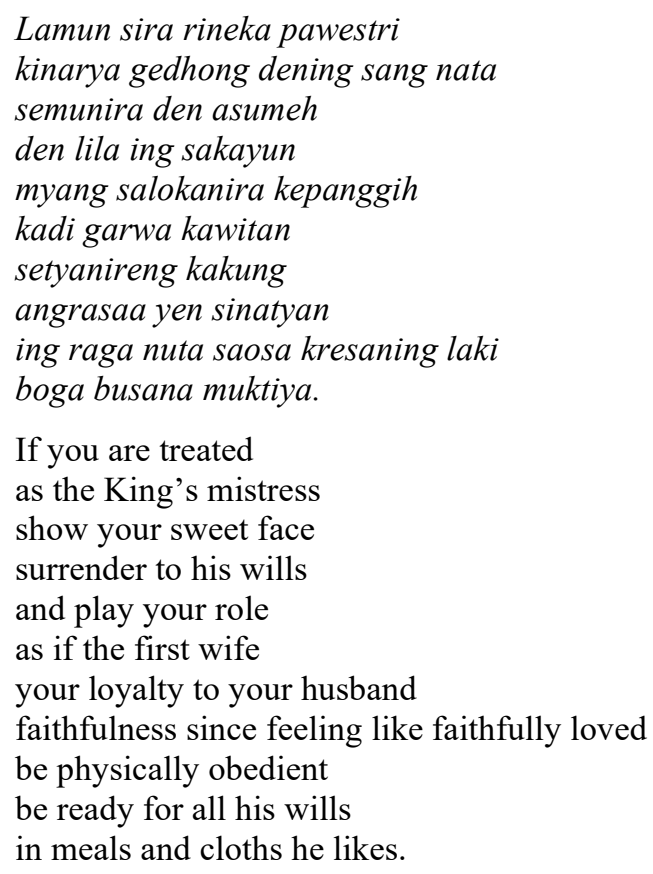

If you are treated as the King's mistress show your sweet face surrender to his wills and play your role as if the first wife your loyalty to your husband faithfulness since feeling like faithfully loved be physically obedient be ready for all his wills in meals and cloths he likes.

The overall meaning of the gurit (poetry) above emphasizes the traits of women who are desired by men in Javanese patriarchal society. Obviously, this is very unfair because the role of women is only as an object and a woman does not have official status; it is only suwargo nunut neraka katut. Whenever a woman is not wanted or disliked, she will be divorced. This results in a dilemma of Javanese women that follow the trend of the era by enrolling in higher education when they are not favored by men, they will only deal with the kitchen, while surrendering to men does not mean they will not be divorced. This is the inequality.

In Wulang Estri verse 8, the song of Dhandanggula was advised by Geniara that his two daughters should be thankful for getting the husband of the son of king Jenggala, marma babo dibegjanira (thank God). The verses 2 and 3 of Kinanthi song stated that the duties carried by 
the wife included devoted to her husband (should subserve her husband), sayekti wajib ngabekti (should really dedicate), because husband is like a king and the king is the representative of God in the world, as can be read in the following quotation:

Mapan ratu kinarya wakil Hyang Agung marentahken kukum hadil pramila wajib den henut kang sapa tan manut hugi mring prentahe sang katong haprasasat mbadal hing karsa Hyang Agung mulane babo wong hurip saparsa ngawuleng ratu kudu heklas lahir batin haja nganti nemu hewoh

Since the queen as the representative of His Majesty commands the law of justice, it must be followed by anyone who does not obey the King's orders same as defying the will of the Great, so all whoever wants to worship the queen must be sincere physically and mentally.do not get into doubt

In Candra Rini it is stated that the husband is like Bathara Di (the Most Great) so that the wife is obliged to serve her husband to get happiness in the household (verses 42 and 43 of the Megatruh song):

Sungku sungkeme ngawula

Maring laki pangrengkuhe

Bathara Di

Ngudi kawidadan

Jrih terus ing lair batin

Cundhuk cumondong ing karsa

Really respectfully devoted

To the husband her respect like a god

Looking for happiness

Reticent until inner and outer

submissive and obedient to the will

[18].

The concept of equality

The concept of equality is actually already owned by Javanese culture. In the Javanese life cycle from birth to death, even while still in the womb, it is always marked with expressing gratitude (slametan). Slametan is a ceremony of gratitude to the Almighty, God Almighty that there are a lot of good fortunes. For example gratitude expressions of neloni, mitoni, brokohan kelahiran, sepasaran, selapanan, setahunan, tedak siti, supitan, and the marriage ceremony which is full of symbolism. Especially for a Javanese woman many ceremonies should be done before she undergoes marriage, for example, siraman, midodareni, panggih, mbasuh ampeyan, kacar-kucur, kembul bujono. The key word for Javanese people is selametan, and in it there is an embodiment of equality, as said by Laksono [19] as follows:

It might even be said that Javanese society exhibits a praxis which goes against the very fibre of the principle of hierarchy: the selametan. One of the hallmarks of Javanese society, the selametan is a familiar, unpretentious commensal ritual performed at such critical junctures in one's life as birth, circumcision, recovery from illness, and even admission to university. 
This was also said by C. Geertz:

When you are at a selametan, nobody feels different from anybody else and so you don't want to all split up. At a selametan everyone is treated equally. Consequently no one feels lower than the others, no one would see the need for humbling himself before his fellows [20].

In the teaching book of Wulang Reh, the teachings are also not only intended for women but also for men. So even at that time in Java there was already a meaning of equality, equality between men and women, or what is called gender equality, as in the following text:

Lamun sira hanggeguru kaki hamiliha manungsa kang nyata ingkang becik martabate sarta kang wruh hing kukum kang ngibadah lan kang wirangi sukur oleh wong tapa hingkang wus hamungkul tan mikir pawehing liyan iku pantes sira guranana kaki sartane kawruhana

If you study, my children (male and female) choose a person who is truly good in dignity and who knows the law (religious rules) who is religious and helpful. It would be better to find a hermit who has looked down (not seen to the top, not arrogant) and does not expect the gift of others that is the person you deserve to be a teacher so you should know The above teaching applies to all children, not differentiated, both for boys and girls. If you want to study, choose a good teacher, also the teachings below:

Tuwa anom éstri lanang, gedhé cilik sudagar miwah tani, nadyan ingkang bongsa luhur, yén ngambah bebotoha, ngadu-adu rérékan apus ing apus, kurang gawéné wong gesang, dadi karem ingbilahi.

young and old, male-female, adult-little, traders and farmers, even from noble groups, but when involved in gambling, in a hoax, the less fortunate of the living, become drowned in misery. Here also not distinguished between women and men teachings for all.

In the song of Wulang Reh above, it can be seen that equality or egalitarianism already exists in Javanese society, in fact all professions in life are valued equally, young and old, male-female, adult-little, traders, farmers, noble people, all referred to and all will get the same treatment. Four habits should also be avoided, namely madat (smoking opium), ngabotohan (gambling), durjana (criminals, thieves), and hati sudagar (trading mentality in all matters). From the analysis of the data above it can be seen that Javanese women in the old literary text are in two positions, domestic and public sector. This is consistent with Irine's findings [21]. In domestic sector which are confined in the house because of the power of the husband in this case the king and royal servants, as parameswari or selir, and public sector, those who have free positions in society. Most of them are women traders and farmers. Women from the lower classes enjoy this confined condition. Javanese women of ordinary class have a strategic social and economic role, which are ready to be abandoned by men (divorced), but Javanese priyayi women (the king's wife and relatives in the palace) are precisely described otherwise. This is consistent with Ismawati's findings [22].

\section{Conclusion}

From the results of the analysis it can be concluded that Javanese women in old Javanese literary texts are described in two descriptions. On the one hand Javanese women are depicted as human beings confined inside the house, restricted access to the outside world (living in the domestic sector), on the other hand Javanese people are already familiar with egalitarianism even though it is only in a small scale and scope, which places women in public places 
(public), as traders, farmers. The socioeconomic status and role of women are also described as being in two descriptions. Women kept at home (as concubines, queen consort) do not have socioeconomic status and roles, but ordinary free women have clear economic roles and status. In fact they have become the pillars of the family economy, as described in Serat Wedhatama (harta, wirya, triwinasis) and Wulang Reh.

\section{Acknowledgments}

Thank you infinitely to Prof. Ocky Karna Radjasa, MSc, PhD as Director of Research and Community Service of the Ministry of Research and Technology who has given us the opportunity to carry out Development Research with sufficient funds. Also thank you to Mr. KRT Darajadi Gondodiprojo and Mrs. Dra. Darweni, M.Hum from Mangkunegaran library, who have designed to be human resources in our research triangulation.

\section{References}

[1] G. Moedjanto, Konsep Kekuasaan Jawa. Penerapannya oleh Raja-raja Mataram. Yogyakarta: Kanisius, 1987.

[2] P. MM, Sosiologi Kontemporer. Jakarta: CV Rajawali, 1987.

[3] T. Parsons, The Social System. London: Psychology Press, 1990.

[4] A. L. Giv and M. M. Nia, "The Status of Women in the Novels of Najib Al-Kilani (Based on two novels of Jakarta's Virgin and The Man Who Believed," Theory Pract. Lang. Stud., vol. 6, no. 6, pp. 1315-1322, 2016.

[5] A. H. Muhammad, "Rasisme dalam Masyarakat Pascakolonial. Analisis Wacana Kritis terhadap Novel-novel Woodson,” Humanus. J. FBS Unversitas Negeri Padang, 2016.

[6] E. Liliani and Esti, "Refleksi Peran Perempuan dalam Novel Indonesia 1900-2000," Litera, vol. 9, no. 1, 2010.

[7] M. Education and Culture, "PSPB." 2016.

[8] Suwondo, T. S. Riyadi, D. Priyoprabowo, and Sukardi, Nilai-nilai Budaya Susastra Jawa. Jakarta: Pusat Bahasa, 1994.

[9] Purbatjaraka, "Karya Sastera Jawa Kuna Yang Berbentuk Tembang," J. Terjem. Alam Tamadun Melayu, vol. 2, no. 1, pp. 101-112, 2010.

[10] E. Ismawati, "Karakter Perempuan Jawa dalam Novel Indonesia Berwarna Lokal Jawa: Kajian Perspektif Gender dan Transformasi Budaya," Metasastra, J. Penelit. Sastra, vol. 6, no. 1, pp. 20-21, 2013.

[11] W. J. Wilson and A. Chaddha, "The Role of Theory in Ethnographic Research," Ethnography, vol. 10, no. 4, pp. 549-564, 2010.

[12] E. Ismawati, "Religiousity in Wedhatama by KGPAA Mangku Negara IV: an Education Model ala Javanese Culture," 2016.

[13] K. Saddhono and S. Supeni, "The role of dutch colonialism in the political life of Mataram dynasty: A case study of the manuscript of Babad Tanah Jawi," Asian Soc. Sci., vol. 10, no. 15, p. 1, 2014.

[14] S. Endraswara, Sastra Etnografi. Yogyakarta: Sastra Morfalingua, 2017.

[15] J. W. Creswell, Qualitative Inquiry and Research Design:Choosing among. London: Sage Publication, 1998.

[16] E. Ismawati, Transformasi Perempuan Jawa. Surakarta: Pustaka Cakra, 2005.

[17] S. Kartodirjo, Perkembangan Peradaban Priyayi. Yogyakarta: Gadjah Mada University Press, 1987.

[18] T. Suwondo, S. Riyadi, D. Priyoprabowo, and Sukardi, Nilai-nilai Budaya Susastra Jawa. 
Jakarta: Pusat Bahasa, 1994.

[19] P. M. Laksono, Tradition in Javanese Social Structure Kingdom and Countryside. Yogyakarta: Gadjah Mada University Press, 1990.

[20] C. Geertz, Abangan, Santri, Priyayi dalam Masyarakat Jawa. Translation. Jakarta: Pustaka Jaya, 1983.

[21] I. H. Frieze, J. E. Parsons, P. B. Johnson, D. N. Ruble, and G. L. Zellman, Women and Sex Roles A Social Psychological Perspective. London: W*W Norton and Company, 1978.

[22] E. Ismawati, "The Status and Roles of Javanese Women in Indonesian Literary Texts," J. Masy. dan Budaya, vol. 20, no. 2, pp. 223-236, 2018. 